AJIT-e: Online Academic Journal of Information Technology

2019 Bahar/Spring - Cilt/Vol: 10 - Sayı/Num: 37

DOI: 10.5824/1309-1581.2019.2.003.x

http://www.ajit-e.org/?menu=pages\&p=details_of_article\&id=425

Received: 06.05.2019

Editorial Process Begin: 27.05.2019

Published: 15.06 .2019

\title{
Sosyal Medya Kullanımı ve Aleksitimi: Acil Serviste Çalışan Hemşireler Üzerine Bir Araştırma
}

Sefer KALAMAN, Yozgat Bozok Üniversitesi Iletişim Fakültesi, Dr. Öğr. Üyesi, sefer.kalaman@bozok.edu.tr, orcid no: 0000-0002-2761-1229

Hilal ORHAN, Yozgat Bozok Üniversitesi İletişim Fakültesi, Lisans Öğrencisi, hilalorhan125@gmail.com, orcid no: 0000-0001-9720-2642

İrem KOCABAY Yozgat Bozok Üniversitesi İletişim Fakültesi, Lisans Öğrencisi, iremkcby99@hotmail.com, orcid no: 0000-0001-8972-9743

Öz

\begin{abstract}
Çalışmanın amacl, acil serviste çalı̧̧an hemşirelerin aleksitimi düzeylerini tespit etmek ve sosyal medya kullanım düzeylerinin aleksitimi durumlarına ne düzeyde etki etiğini ortaya çıkarmaktır. Araştırmada nicel araştırma yöntemlerinden biri olan anket tekniği kullanılmış ve veriler katılımcılarla yüz yüze anket tekniği kullanılarak elde edilmiştir. Araştırmanın evrenini, Türkiye'nin İç Anadolu bölgesinde bulunan Ankara ve Yozgat illerindeki 116 hastanede görev yapan yaklaşık 8105 acil servis hemşiresi oluşturmaktadır. Araştırmanın örneklemini ise, bu illerdeki toplam 30 hastanede görev yapan 236 acil servis hemşiresi teşkil etmektedir. Çalışmada elde edilen bulgulara göre, acil serviste çalışan hemşirelerin aleksitimi düzeyleri düşük olmaktadır. Bunun yanında sosyal medyayı daha az kullanan hemşirelerde aleksitiminin daha az görüldü̆̈̈̈ tespit edilmiştir. Çalışmada ayrıca katılımciların aleksitimi düzeyleri, cinsiyet, yaş, medeni durum, eğitim, meslek yılı ve yaşanılan şehir temelinde incelenmiş ve anlamlı farklılıklara ulaşılmıştır.
\end{abstract}

Anahtar Kelimeler: İnternet, Sosyal Medya, Sosyal Paylaşım Ağlarl, Aleksitimi, Hemşireler

\section{Social Media Usage and Alexithymia: A Research on Nurses Working in Emergency Service}

Abstract The aim of this study was to determine the alexithymia levels of emergency nurses and to reveal the connection between social media usage level of emergency nurses and their alexithymia. The survey technique, which is one of the quantitative research methods, was used in the study and the data were obtained with face to face survey technique. The population of the research is about 8105 emergency nurses that work 116 hospital in Ankara and Yozgat. The sample of the study is 236 emergency nurses that work this 30 hospitals. According to the findings of the study, the alexithymia levels of emergency nurses are low. In addition, it was found that alexithymia is less common in nurses who use less social media. In the study, alexithymia levels of the participants were examined on the basis of gender, age, marital status, education, occupational year and the city of living and significant differences were reached.

Keywords: Internet, Social Media, Social Networks, Alexithymia, Nurses

\section{Giriş}

Tek yönlü iletişimin hakim olduğu ve kullanıcıların içerik üretme imkanının olmadığ 1 web 1 teknolojisinden sonra insan hayatına giren web 2 teknolojisi, başta sosyal paylaşım ağları 
olmak üzere birçok sanal ortamın doğmasına zemin hazırlamış ve kullanıcıları bilgi veren, paylaşımda bulunan, bilgiyi ürettiren konumuna yani iletişim sürecinde aktif konuma getirmiştir. Geleneksel medyadan farklılaşarak iletişim alanını kökten değiş̧iren bu dijital ortam ya da tümdeşik medya ortamı, yeni medya bazı araştırmacılara göre ise sosyal medya olarak adlandırılmaktadır.

İletişim teknolojisindeki bu gelişme bireylerin yaşam şekillerini değiştiren en büyük etkenlerden biri olarak karşımıza çıkmaktadır. Bu teknolojik gelişme sayesinde, insanlar arasındaki bilgi paylaşımı çok hızlı biçimde gerçekleşebilmektedir. Bununla birlikte mobil iletişimin internet ile yakınsaması sonucu, zaman ve mekan kavramlarının önemi ortadan kalkmaktadır. İnsanlar arasında bilginin çok hızlı bir biçimde paylaşılmaya başlamasıyla beraber, yeni sosyalleşme mekanları ortaya çıkmaktadır. Bu durum, dönem içerisinde sosyal medyanın popülaritesinin artmasıyla her türlü iletişimin bu ağlar aracılığıyla gerçekleştirilmeye başlandığı görülmektedir. Meydana gelen bu gelişmeler, insanların/toplumların ilişkilerini, iletişimlerini, sosyalleşme süreçlerini, yaşam biçimlerini, çevreyle olan etkileşimlerini derinden etkilemektedir (Karagülle ve Çayc1, 2014: 2).

İnsan hayatına getirdiği yenilik ve kolaylıkların haricinde sosyal medya, birçok araştırmacı tarafından insanlar üzerindeki olumsuz etkilerinden dolayı zararlı, tehlikeli ya da önlem alınması gereken bir iletişim ortamı olarak ifade edilmektedir. Sosyal medyanın neden olduğu ya da sosyal medya aracılığıyla tetiklenen/artan fizyolojik ve psikolojik hastalıklar bu olumsuzluğun en önemlilerinden birkaçı olmaktadır. Sosyal medya bağımlılığı, obezite, sanal benliğe bağlanma vb. gibi hastalıkların haricinde toplum nezdinde çok fazla bilinmeyen hastalıklardan birisi ise aleksitimidir. Aleksitimi aslı itibariyle psikosomatik hastalıkları olan bireylerin duygularını açıklamada yaşadıkları zorlukları açıklamak için ortaya konulan bir kavram (Sifneos, 1972) olsa da ilerleyen yıllarda farklı bilim dallarında yapılan araştırma neticesinde aleksitiminin oluşmasına neden olan birçok farklı etmenin (Kişisel özellik, kültür vd.) bulunduğu ortaya konulmuştur.

Aleksitimi, bireyin, duygularını tanımlamada ve duygularını ifade etmede yaşadığı zorluk durumu olarak ifade edilmektedir. Aleksitimi, literatürde, duygusal sağırlık, duygu körlüğü, duygulara söz bulamamak gibi ifadelerle de açıklanmaya çalışılmaktadır. Yapılan araştırmalarda, aleksitiminin ortaya çıkmasını tetikleyen ya da bireydeki aleksitimi durumunun artmasina neden olan etmenlerden birisinin de sosyal medya olduğu ortaya konulmaktadır. Aleksitimikler hastalıkları nedeniyle hem yakın ilişkilerinde, hem ailevi ilişkilerde hem de çevresindeki (okul hayatı, iş hayatı, arkadaş çevresi vd.) diğer ilişkilerde sorunlar yaşamaktadır. Bu sorunlardan kaçınmak ve normal ruhsal sağlı̆̆a sahip bir birey gibi davranmak isteyen aleksitimikler rol yapma yoluna gidebilmektedir.

Toplumda farklı misyonlara sahip olan insanlar bu psikolojik rahatsızlık hasebiyle kişisel ilişkilerinin haricinde mesleklerini de icra ederken sorun yaşayabilmektedir. Bu mesleklerin en önemlilerinde birisi de kuşkusuz hemşireliktir. Özelikle acil serviste çalışan hemşirelerin gerek hastalarla acilen ilgilenmeleri gerekse de hasta yakınları ile doğru ve etkili bir iletişim kurmaları, temelde empati kurma karşıdakinin duygularını anlayabilme ve kendi duygularını da ifade edebilmekten geçmektedir. Bu noktadan hareketle çalışmada, acil serviste çalışan hemşirelerin aleksitimi düzeylerini ortaya çıkarmaya ve sosyal medya kullanımının aleksitimi ile olan ilişkisini tespit etmeye çalışılmıştır. 


\section{Sosyal Medya ve Hastalıklar}

Dijital devrim diğer bir değişle internet devrimi, radyo, televizyon, gazete gibi kanallar aracılığıyla hayat bulan geleneksel medyanın görece popülerliğini ve kullanımını azaltmış ve yeni medyanın insanlar tarafından daha fazla ve daha farklı şekillerde kullanılmasına imkan sağlamıştır. Sosyal medya olarak da tabir edilen bu platformda bireyler özgürce düşüncelerini, herhangi bir durum karşısındaki tutumlarını dile getirebilme ve dünyanın başka bir merkezinde meydana gelen bir olay hakkında dahi fikir beyan edebilme, destekleme veya eleştirebilme olanağını bulmuştur. Laptop, tablet, e-book, netbook, İ-pod, PDA'lar ve akıllı cep telefonları aracılığıyla da her geçen süre daha fazla yaygınlaşan ve kullanılabilen sosyal medya, modern insanın gündelik rutinini oluşturur hale gelmiştir (Uygun ve Akbulut, 2018: 76-77; Şentürk, 2013: 29).

Sosyal medya, insanların zamandan ve mekandan bağımsız olarak bir araya gelip iletişim kurdukları, kullanıcılarına kendi bağlantı listelerini açıklamalarına/oluşturmalarına olanak sağlayan, farklı medya, bilgi ve iletişim teknolojilerini içinde barındıran sanal bir iletişim ortamıdır (Fuchs, 2011: 141). Birçok sanal ortamı bünyesinde barındıran sosyal medyayı, eposta grupları, bloglar, mikrobloglar, wikiler, forumlar, podcastler, kurumsal intranet (kurum içi ağ), extranet (tedarikçi ve kurumsal müşterilerle oluşturulan ağ), hızlı mesaj servisleri ve sosyal paylaşım ağları (WeChat, QQ, Instagram, Facebook, vb.) şeklinde sinıflandırmak mümkündür (Mayfield, 2019: 6; Onat ve Alikılıç, 2008: 1118).

$\mathrm{Bu}$ sanal iletişim ortamlarının gündelik hayata entegre olması insanların yaşamında köklü değişimlerin yaşanmasına neden olmuştur. Çevrim içi topluluklarda ve sanal alanlarda gerçekleştirilen elektronik iletişim, yüz yüze iletişimin yerini almıştır. Bu durum bireyi gerçek dünyadan ve sosyal ilişkilerden koparmakta sanal alem üzerinde izole edilmiş alanlar içerisine hapsetmektedir. Kuşkusuz bu alanlarda da bir ilişki kurulmakta ve bir sosyal etkileşim gerçekleşmektedir, ancak bu ilişkilerin dayandığı temeller, gerçek ve yüz yüze ilişkilerin doğasından ve karakteristik yapısından oldukça uzakta yer almaktadır (Ersoy, 2013: 18-19). Karagülle ve Çaycı'nın da (2014: 3) dediği gibi, "sanal ortamda vuku bulan bu durum, zihin ve beden arasındaki ayrılmaz birlikteliğin endişe verici bir biçimde kopmasına sebebiyet vermektedir". Sosyal medyada gerçekleştirilen iletişimin haricinde, bu ortamdaki paylaşımlar, oynanan oyunlar, geçirilen boş zaman aktiviteleri ve diğer uygulamalar ile birey hayatının önemli bir bölümünü bu dijital alanda yaşamaktadır. Sosyal medya, sağladığı olumlu imkanlar ile insanların hayatında pozitif bir etki yaratabilmekte ancak aynı zamanda bir takım hastalıklara ve olumsuzluklara da neden olduğu için de insanların yaşamına zarar verebilmektedir.

Sosyal medya, nomofobi, ortopedik sorunlar, sosyal paylaşım ağlarından uzak kalamama, insan ilişkilerine ayrılan zamanın azalması, sosyal izolasyon, dikkat bozukluğu, internet bağımlılığı, benlik saygısının azalması, yalnızlaşma, depresyon, fiziksel rahatsızlıklar, photolurking, yabancılaşma ve daha birçok fiziksel, sosyal ve psikolojik rahatsızlığa neden olabilmektedir. Sosyal medya kaynaklı bu rahatsızlıklar, bireyin iç dünyasını, aile içi etkileşimini, diğer insanlarla olan iletişimini ve buna bağlı olarak meslek hayatındaki verimliliğini de doğrudan etkilemektedir. 
Öyle ki, Stokowski'ye (2011) göre, bireyi tüm iş arkadaşları ile aynı sanal ortamda/mekanda buluşturan sosyal medya, insanların kişisel ve mesleki bulanıklıklara maruz kalmasına neden olabilmektedir. Karagülle ve Çaycı'ya (2014: 3) göre de, bu ortam bireyin zihninde adeta sınırsız bir hareket alanı sağlamaktadır. Ancak bu eylemi gerçekleştirirken beden neredeyse tamamen hareketsiz bir biçimde sabitlenmekte ve sadece birkaç parmak hareketiyle zihindekiler sayısal ortama aktarılmaktadır. Bu durumun sonucunda da çağın önemli sorunlarından olarak görülen obezite hastalığının görülme oranı artmaktadır. Bunun yanında sanal ağda sanal bir sosyalleşme içerisine giren birey aslı itibariyle gerçek hayatta yalnızlaşmaktadır.

Sosyal medya, neden olduğu rahatsızlıkların yanında kimi durumlarda da var olan rahatsızlıkların tetiklenmesine ya da şiddetlenmesine de neden olabilmektedir. $\mathrm{Bu}$ rahatsızlıklardan birisi ise duygusal sağırlık yahut duyguları ifade etmede güçlük olarak ifade edilen aleksitimidir. Daha çok klinik hastalarda görülen aleksitimi, her geçen gün yaygınlığını arttırmakta ve artık toplumun genelinde de sıkça görülmektedir. Öyle ki, aleksitimi artık ergenlerde dahi görülmeye başlanmakta ve ergenler açısından önemli bir soruna işaret etmektedir. (Bolat vd., 2017: 362). Koçak'a (2002: 186) göre Çağın modern toplumlarında hızla artan nüfus ve gelişen teknoloji ile birlikte karmaşık ve doyumsuz insan ilişkileri arasında yalnızlığa sürüklenen günümüz insanında bilgisayar, internet ve sosyal medyanın kullanımının yaygınlaşmasına paralel olarak aleksitimik özelliklerde artışlar olduğu gözlenmektedir.

\section{Aleksitimi ve Acil Serviste Çalışan Hemşireler}

Psiko-sosyal bir varlık olan insan, varlığını sürdürmek ve ihtiyaçlarını karşılamak için toplu halde yaşamaya ve diğer insanlarla iletişim kurmaya ihtiyaç duymaktadır. Birlikte olmak ve yaşamı devam ettirmek için iletişim kurmak insanı diğer varlıklardan ayıran en önemli özelliklerinden biri olmaktadır. İnsanın günlük yaşamında sağlıklı ve dengeli ilişkiler kurmasında ve iletişim sürecinde başarıya ulaşmasında, duygu, düşünce, davranış ve fizyolojik tepkiler bir bütün olarak önem arz etmektedir. Bu bütünlüğün bozulması sosyal varlık olarak denge ve uyum arayışında olan insan için bir tehdit oluşturmaktadır. Bu açıdan bakıldığında sağlıklı ve dengeli ilişkiler kurmadaki bütünlüğü sağlayan en önemli unsurlardan birisi beki de en önemlisi insanın iç dünyasının aynası olan duygulardır. Çünkü duygular yaşamın tümünü etkileyebilecek, yaşamın amacını ve anlamını oluşturacak özelliğe ve öneme sahip olmaktadır. İnsan, duygu ve düşünceleri fark edip anlamlandırarak ve onları sözel olarak ifade ederek iletişim kurmakta ve kurduğu iletişimle yaşamını idame ettirmektedir (Koçak, 2002: 183). Ancak bu denli önemli olan, duyguların farkına varma ve duyguları ifade etme eylemlerinin gerçekleştirilememesi bireyin ruhsal ve fiziksel sağlı̆̆ının bozulmasına ve diğer insanlarla sağlıklı ve dengeli iletişim kuramamasına neden olmaktadır.

Duyguları tanımlamada ve duyguları ifade etmede yaşanan zorluk durumu, literatürde psikolojik bir rahatsızlık olan aleksitimi ile ilişkilendirilmektedir. Latince kökenli bir kelime olan aleksitimi, duygusal sağırlık, duygu körlüğü, duygulara söz bulamamak gibi açıklamalarla ifade edilmektedir. Aleksitimi terimi, ilk defa Sifneos (1972) tarafından psikosomatik hastalıkları olan bireylerin duygularını ifade etme güçlügüunü vurgulamak için kullanılmıştır. 
Yenilikçi klinik gelişmelerde yararlanılabilecek bir kavram olarak ortaya çıkmış fakat zamanla sınırları muğlaklaşmış olan bu kavram, farklı alanlarda yapılan araştırmalar sayesinde oldukça geniş bir alana yayılmıştır (Şaşıŏ̆lu vd., 2013: 508). Bunun neticesinde, literatürde, aleksitiminin kişisel bir eğilim, yetersiz sosyal destek sonucu ortaya çıkan bir durum, psikolojik bir bozukluk ya da klinik bir belirti, psikosomatik hastalık, bilişsel bozukluk, kişilik özelliği veya nörolojik bir problem olduğu gibi pek çok farklı görüş ortaya atılmıştır (Epözdemir, 2012: 26).

Aleksitimi üzerine çalışmalar yapan araştırmacılar, aleksitimik bireylerin genel çerçevede beş belirgin özelliğini saptamışlardır. Bunlar; duygusal deneyimlerde bir azalma ya da yetersizlik, duyguları sözlü olarak ifade etmede azalma ya da yetersizlik, hayal kurma, düşlem yaşamında azalma ya da yetersizlik, başkaları ile empati kurmada, başkalarını anlamada yetersizlik ve duyguları tanımlamada zorluk olarak belirlenmiştir (Hendryx et. al., 1991; Taylor et. al., 1985). Bunun yanında aleksitimik bireylerin daha fazla bağımlı olma eğilimleri bulunmaktadır. Aleksitimikler, çevrelerine çok sosyal ve paylaşıma açık bireylermiş gibi görünmelerine rağmen aslı itibariyle bu özelliklere sahip bulunmamakta olup bir nevi rol yapma eyleminde olmaktadır. Aleksitimik kişiler duygusal sağırlıklarından ötürü hiç ağlamamakta ya da çok nadiren ağlamaktadır (Kauhanen et. al, 1993).

Aleksitimi başlangıçta psikoanalitik kuramcılar tarafından psikosomatik hastalıklara özgü bir semptom olarak ortaya atılmıştır. Aleksitiminin klinik tanımlamasında somatizasyonun çok önemli bir yer tutmasına ve psikosomatik hastalıklara yakın bulunmasına rağmen, yapılan araştırmalarda aleksitimi ile psikosomatik hastalıklar arasında doğrudan net bir ilişki olduğu söylenememiştir. Ayrıca son yıllarda özellikle 1980 sonrasında yapılan araştırmalarda aleksitiminin yalnızca klinik hastalarda, psikosomatiklerde görülen bir özellikle olmadığı, aynı zamanda normal popülasyonda sağlıklı bireylerde de sıkça görüldüğü tespit edilmiştir (Koçak, 2002: 186).

$\mathrm{Bu}$ alanda yapılan araştırmalar neticesinde genel popülasyonda da sıkça görülebilen aleksitimiyi yordamada, bireyin eğitim düzeyi, bağlanma tarzları, benlik algısı ve kişilerarası ilişkilerde sergilenen besleyici tarz ve öfke önemli değişkenler olarak bulunmuştur. Burada dikkat edilmesi gereken nokta, tüm bu değişkenlerin birbirleriyle yakın ilişki içinde olduğudur. Bireyin yaşamının ilk yıllarında edindiği bağlanma tarzları ile ilerleyen yaşam sürecinde edindiği kişilerarası ilişki tarzları, öfke ve benlik algısının aleksitimik özellikler üzerinde önemli bir etkisinin olduğu düşünmek mümkündür. Aleksitimik bireyler, daha çok kaygılı ve kaçınmacı bağlanma türüne sahip oldukları için kişilerarası ilişkilerde zorluk yaşamaktadır, bu durum ise öfkenin içe dönük tepkiler ve saldırgan davranışlar şeklinde yaşanmasına yol açabilmektedir. Tüm bunlar ise benlik saygısında bir düşüşe ve bu yüzden tekrar kişilerarası ilişkilerde sorunlara ve öfkeye, yani kısır bir döngüye neden olmaktadır (Oktay ve Batıgün, 2014: 38). Bu durum, bireyin gündelik yaşamında hayatını sağlıklı ve başarılı bir şekilde sürdürebilmesinin önünde büyük bir engel teşkil etmektedir. Bu aşamada aleksitimik bireyin yapmış olduğu meslek de onun kurduğu problemli ilişkinin önemini daha da arttırmaktadır. Öyle ki öğretmenlik, doktorluk, hemşirelik gibi meslekleri icra eden bireylerin duygusal açıdan diğer insanlara göre daha sağlıklı olmaları gerekmektedir.

Parlayan ve Dökme'nin (2016: 266) de dediği gibi, insanların hayatında vazgeçilmez bir alan olan iletişimi, sağlıklı duygu ve düşünce alışverişini, sağlık alanında düşündüğümüzde 
durumun öneminin daha fazla arttığı görülmektedir. Özellikle acil serviste çalışan hemşirelerin gerek hastalarla gerekse de hasta yakınlarıyla kuracağı iletişimin temelinde, duyguları anlama, empati kurabilme ve karşıdaki bireye duyguyu aktarabilme yatmaktadır.

Sağlık çalışanları özelinde yapılan araştırmalar incelendiğinde, özellikle hemşirelerin empati ve iletişim becerilerini araştıran bir çok çalışmaya rastlanmaktadır. Ancak hemşirelerin iletişim ve empati becerilerin gelişimini olumsuz etkileyebileceği düşünülen aleksitimi gibi durumların araştırıldığı çok az çalışma bulunmaktadır (Aksoy ve Çoban, 2017: 46). Kamel'in (2013) empati ve hastane çalışanları özelinde gerçekleştirdiği araştırma, aleksitimik kişilik özeliğine sahip hemşirelerin empati yeteneğinin daha sınırlı olduğu sonucuna varılmış ve bu hemşirelerin diğer insanlara nazaran kişilerarası ilişkilerde daha çok problem yaşadıkları ortaya çıkarılmıştır.

Bu noktadan hareketle yapılan çalışmada, acil servis hemşireleri, aleksitimi ve sosyal medya arasındaki ilişki incelenmiştir. Araştırmada, acil servis çalışanlarının aleksitimi düzeyleri, sosyal medya kullanan acil servis hemşirelerinin kullanmayanlara göre aleksitimi olma düzeylerinde bir farklılık bulunup bulunmadığı ve farklı değişkenlerin aleksitimi ile arasındaki ilişki ayrıntılı olarak ele alınmıştır.

\section{Araştırmanın Metodolojisi}

\section{Araştırmanın Amacı, Önemi ve Literatüre Katkısı}

Çalışmada, Ankara'daki ve Yozgat'taki acil serviste çalışan hemşirelerin sosyal medya kullanım alışkanlıklarını ve aleksitimi düzeylerini tespit etmek amaçlanmaktadır. Araştırmada ayrıca hemşirelerin sosyal medya kullanım düzeylerinin aleksitimi durumlarına ne düzeyde etki etiğini ortaya çıkarmak amaçlanmaktadır.

Hemşirelik mesleği halihazırda bir çok zorluğu bünyesinde barındırmaktadır. Ancak acil servis hemşirelerinin ağır ve acil vakalarla/hastalarla ilgilenmesi gerekliliği onları diğer hemşirelerden farklı kılmaktadır. Bu noktada acil servis hemşirelerinin hem kendilerine karşı hem de hasta ve hasta yakınlarına karşı psikoloji ve iletişim konularında daha becerikli ve yetkin olmaları beklenmektedir. Psikolojik olarak durumdan etkilenmeleri onların ruh sağlığına zarar verebilecekken, durumdan hiç etkilenmemeleri de onların duygusal sağırlığa (aleksitimi) maruz kalmalarına neden olabilmektedir. Bu nedenle çalışma, hemşirelerin aleksitimi düzeylerini ortaya çıkaracak olması, bunun yanında sosyal medya kullanan ve kullanmayan hemşireler arasında aleksitimi noktasında bir fark olup olmadığını tespit edecek olması açısından önemli olmaktadır.

Aleksitimi ile ilgili literatür incelendiğinde, yapılan araştırmaların daha çok ergenlerle, lise öğrencileriyle, hemşirelik bölümünde okuyan üniversite öğrencileriyle, doktorlarla ve alkol bağımlılarıyla yapıldığı görülmektedir. Çalışmanın, acil serviste çalışan hemşirelerle yapılması bu noktada literatüre diğer meslek ve kişilerin yanında ayrıca bir katkı sağlayacağ düşünülmektedir. Araştırma, sosyal medya, aleksitimi, duyarsızlaşma ve Toronto Aleksitimi Ölçeği konularında literatür taraması içermektedir. Bu nedenle çalışmanın yapılacak diğer bilimsel çalışmalara veri oluşturacak olması nedeniyle önemli olduğu düşünülmektedir.

\section{Araştırmanın Yöntemi, Evreni ve Örneklemi}


Araştırmada verileri elde etmek için Ankara ve Yozgat'taki hastanelerde çalışan acil servis hemşireleri ile saha araştırması yapılmıştır. Araştırmada nicel araştırma yöntemlerinden biri olan anket tekniği kullanılmıştır. Araştırmanın ayrıca aşağıdaki hipotezler sınanmıştır.

H1: Acil serviste çalışan hemşirelerin aleksitimi düzeyleri düşüktür.

H2: Sosyal medyayı kullanan hemşireler kullanmayanlara oranla daha yüksek aleksitimiye sahiptir.

H3: Hemşirelerin yaşları ve meslekte çalışma süreleri arttıkça aleksitimi düzeyleri de artış gösterir.

Araştırmanın evrenini, Türkiye'nin İç Anadolu bölgesinde bulunan Ankara ve Yozgat illerindeki 116 hastanede görev yapan yaklaşık 8105 acil servis hemşiresi oluşturmaktadır. Araştırmanın örneklemini ise, bu illerdeki toplam 30 hastanede görev yapan 236 acil servis hemşiresi oluşturmaktadır. Anket çalışmasında örneklemin evreni temsil etmesi açısından anketler, şehirlerin sahip olduğu hastanelerin sayısı baz alınarak orantısal olarak dağıtılmıştır. Bu sebeple anket çalışması Ankara'da 23, Yozgat'ta ise 7 özel ve devlet hastanesinde yapılmıştır. Örneklem, gruplara göre örnekleme yöntemi kullanılarak belirlenmiştir.

\section{Veri Toplama Araçları ve Analiz}

Çalışmada, Ankara ve Yozgat'taki acil serviste çalışan hemşirelerin sosyal medya kullanım düzeylerini ve aleksitimi durumlarını ortaya çıkarmak için yapılan anket çalışması, Ocak 2019 - Mart 2019 tarihleri arasında yapılmış ve veriler katılımcılarla yüz yüze anket yöntemi kullanılarak elde edilmiştir. Anket hazırlanırken Taylor ve arkadaşlarının 1985 yılında oluşturmuş olduğu Toronto Aleksitimi Ölçeğinden yararlanılmıştır. Toronto Aleksitimi Ölçeği (TAÖ-20), duygularını tanıma zorluğu, duygularını ifade etme zorluğu ve dışa dönük düşünce olmak üzere üç alt boyuttan ve bu boyutlara ait toplam 20 sorudan oluşmaktadır. Ölçek, likert tipi (beşli) bir ölçme aracı olmakta ve ölçekten en fazla puan 100, en az ise 20 puan alınabilmektedir. Ölçeğin tamamından 51 ve altında puan alanlar aleksitimik olmayan gruba, 52-60 arasında puan alanlar orta derecede aleksitimik grubuna, 61 ve üzerinde puan alanlar ise tamamen aleksitimik grubuna dahil edilmiştir. Veriler SPSS 20 paket program kullanılarak analiz edilmiş ve verilerin analizinde Sıklık Analizi, Shapiro-Wilk Testi, MannWhitney U testi ve Kuruskal-Wallis testi kullanılmıştır

\section{Bulgular}

Çalışmaya dahil olan acil serviste çalışan hemşirelerin demografik bilgileri incelendiğinde, katılımcıların çoğunluğunun kadın $(\% 67,8)$ olduğu, büyük bölümünün $(\% 63,1)$ 18-34 yaş aralığında bulunduğu, yarısına yakının (\%51,3) evli olduğu, çoğunluğunun $(\% 58,4)$ en az bir lisans programında mezun olduğu, önemli bir kısmının $(\% 40,6)$ en az 11 yıldır bu mesleği icra ettiği ve büyük çoğunluğunun mesleğini Ankara'da $(\% 79,2)$ sürdürdüğü görülmektedir (Tablo 1).

Tablo 1. Demografik Özellikler

\begin{tabular}{llll}
\hline & Kategoriler & Sayı & $\mathbf{\%}$ \\
\hline Cinsiyet & Kadin & 160 & 67,8 \\
& Erkek & 76 & 32,2
\end{tabular}




\begin{tabular}{|c|c|c|c|}
\hline \multirow[t]{4}{*}{ Yaş } & $18-24$ & 84 & 35,6 \\
\hline & $25-34$ & 65 & 27,5 \\
\hline & $35-44$ & 66 & 28,0 \\
\hline & $45+$ & 21 & 8,9 \\
\hline \multirow[t]{2}{*}{ Medeni Durum } & Evli & 121 & 51,3 \\
\hline & Bekar & 115 & 48,7 \\
\hline \multirow[t]{4}{*}{ Eğitim } & Lise & 43 & 18,2 \\
\hline & Önlisans & 55 & 23,4 \\
\hline & Lisans & 132 & 55,9 \\
\hline & Lisansüstü & 6 & 2,5 \\
\hline \multirow[t]{5}{*}{ Meslek Y1lı } & $1-5$ yil & 91 & 38,6 \\
\hline & $6-10$ yil & 49 & 20,8 \\
\hline & $11-15$ y1l & 56 & 23,7 \\
\hline & $15-20$ yil & 23 & 9,7 \\
\hline & 20 yıldan fazla & 17 & 7,2 \\
\hline \multirow[t]{3}{*}{ Yer } & Ankara & 187 & 79,2 \\
\hline & Yozgat & 49 & 20,8 \\
\hline & Toplam & 236 & 100 \\
\hline
\end{tabular}

Katılımcıların internet ve sosyal medya kullanım örüntülerine bakıldığında ise, büyük bir kısmının $(\% 71,2)$ internete günde en fazla 3 saat girdiği, interneti en çok $(\% 45,3)$ internette gezinmek için kullandığı, çok büyük bir kısmının $(\% 87,3)$ sosyal medyayı kullandığı, büyük bir kısmının $(\% 67,4)$ en fazla 2 sosyal paylaşım ağına sahip olduğu, büyük bir kısmının yine $(\% 72,9)$ sosyal medyayı günde en fazla 3 saat kullandığı ve medyaya en fazla $(\% 32,6)$ gündemi takip etmek için girdikleri görülmektedir (Tablo 2).

Tablo 2. Internet ve Sosyal Medya Kullanımı

\begin{tabular}{llll}
\hline & Kategoriler & Sayi & $\mathbf{\%}$ \\
\hline İnternet Kullanım Saati & 1 saatten az & 40 & 17,0 \\
& $1-3$ saat & 128 & 54,2 \\
& $4-6$ saat & 55 & 23,3 \\
& $7-9$ saat & 10 & 4,2 \\
& 9 saatten fazla & 3 & 1,3 \\
İnternet Kullanım Amacı & Sosyal paylaşım ağlarına girmek & 76 & 32,2 \\
& Araştırma yapmak, bilgi edinmek & 24 & 10,2 \\
& İnternette gezinmek & 107 & 45,3 \\
& Oyun oynamak & 17 & 7,2 \\
& Diğer & 12 & 5,1 \\
Sosyal Medya Kullanma & Evet & 206 & 87,3 \\
& Hayır & 30 & 12,7 \\
& 1 & 62 & 26,3 \\
& 2 & 97 & 41,1 \\
& 3 & 43 & 18,2 \\
& 4 & 7 & 3,0 \\
\hline
\end{tabular}




\begin{tabular}{llll}
\hline & 4'ten fazla & 1 & 0,4 \\
Sosyal Medya Saati & Kullanmiyorum & 26 & 11,0 \\
& 1 saatten az & 56 & 23,7 \\
& $1-3$ saat & 116 & 49,2 \\
& $4-6$ saat & 30 & 12,7 \\
& 7-9 saat & 9 & 3,8 \\
& 9 saatten fazla & 1 & 0,4 \\
Kosyal Medya Amaç & Kullanmiyorum & 24 & 10,2 \\
& Fotoğraf, video ve yazı paylaşmak & 22 & 9,3 \\
& Arkadaşlarımın paylaşımlarını takip etmek & 67 & 28,4 \\
& Gündemi takip etmek & 77 & 32,6 \\
& Arkadaşlarımla iletişim kurmak & 41 & 17,4 \\
& Diğer & 7 & 3,0 \\
& Kullanmiyorum & 22 & 9,3 \\
& Toplam & $\mathbf{2 3 6}$ & $\mathbf{1 0 0}$ \\
\hline
\end{tabular}

Çalışmada, katılımcıların aleksitimi düzeylerini ölçmek için yapılan analiz sonucuna göre, "duyguları tanımada zorluk" ve "duyguları ifade etmede zorluk" alt boyutlarında katılımcıların aleksitimik olmadıkları ancak "dışa dönük düşünce" alt boyutunda katılımcıların orta derecede aleksitimik oldukları tespit edilmiştir. Genel çerçevede ise $(46,32)$ katılımcıların aleksitimik olmadıkları ancak orta derecede aleksitimik olmaya çok yakın oldukları görülmektedir (Tablo 3).

Tablo 3. Aleksitimi Düzeyi

\begin{tabular}{lll}
\hline & \multicolumn{2}{c}{ Aleksitimi Düzeyi } \\
\cline { 2 - 3 } & Ortalama & Puan \\
\hline Duyguları Tanımada Zorluk & 1,8565 & 37,13 \\
Duyguları İfade Etmede Zorluk & 2,4593 & 49,19 \\
Dışa Dönük Düşünce & 2,6324 & 52,65 \\
Genel & 2,3130 & 46,32 \\
\hline
\end{tabular}

Katılımcılardan elde edilen verilerin, normallik analizi ile normal dağılıp dağılmadığına bakıldığında, Shapiro-Wilk testi sonucuna göre verilerin normal dağılmadığı sonucuna ulaşılmıştır. Bu nedenle verilerin analizinde parametrik olmayan Mann-Whitney U testi ve Kuruskal-Wallis testi kullanılmıştır.

Mann-Whitney U testinden elde edilen sonuçlara göre, \%5 anlamlılık seviyesinde cinsiyet ile aleksitimi arasında anlamlı bir farklılık olmamaktadır. Ancak medeni durum ile aleksitimi arasında \%5 anlamlılık seviyesinde anlamlı bir farklılık bulunmaktadır. Bekar bireylerin aleksitimi düzeyleri evli bireylere göre daha fazla olmaktadır. Aynı şekilde yaşanılan yer ile aleksitimi arasında da anlamlı bir farklılık vardır. Yozgat'ta yaşayan katılımcıların aleksitimi düzeyleri Ankara'da yaşayan katılımcılara göre daha fazla olmaktadır (Tablo 4).

Tablo 4. Cinsiyet, Medeni Durum ve Yaşanılan Yere Göre Aleksitimi Düzeyi

Aleksitimi Düzeyi 


\begin{tabular}{lllc}
\hline Variables & $\mathrm{N}$ & $\mathrm{M}$ & $\mathrm{p}$ \\
\hline Cinsiyet & & & \\
$\quad$ Kadın & 160 & 120,03 & 0,62 \\
$\quad$ Erkek & 76 & 115,27 & \\
Medeni Durum & & & \\
$\quad$ Evli & 121 & 100,99 & 0,00 \\
$\quad$ Bekar & 109 & 131,61 & \\
Yaşanılan Yer & & & 0,01 \\
$\quad$ Ankara & 187 & 112,73 & \\
$\quad$ Yozgat & 49 & 140,52 & \\
\hline
\end{tabular}

* Mann-Whitney U test

Kuruskal-Wallis testinden elde edilen sonuçlara göre ise, \%5 anlamlılık seviyesinde yaş, meslekte çalışma süresi, eğitim düzeyi ile aleksitimi arasında anlamlı farklılıklar mevcuttur. 45 veya üzeri yaşta bulunan katılımcılar daha küçük yaştaki katılımcılara göre daha fazla aleksitimik olmaktadırlar. Aynı şekilde 20 yıldan fazladır bu mesleği icra eden katılımcıların aleksitimi düzeyleri, bu mesleği daha az zamandır yapan katılımclara göre daha fazladır. Ayrıca lise düzeyinde eğitim seviyesine sahip olan katılımcılar, daha fazla eğitim düzeyine sahip olan katılımcılara göre daha fazla aleksitimik olmaktadırlar (Tablo 5).

Tablo 5. Eğitim Düzeyi, Yaş ve Meslek Yılına Göre Aleksitimi Düzeyi

\begin{tabular}{llll}
\hline & \multicolumn{3}{c}{ Aleksitimi Düzeyi } \\
\cline { 2 - 4 } Variables & $\mathrm{N}$ & $\mathrm{M}$ & $\mathrm{p}$ \\
\hline Yaş & & & \\
$18-24$ & 65 & 131,78 & 0,00 \\
$25-34$ & 66 & 116,31 & \\
$35-44$ & 21 & 95,95 & \\
45 ve üzeri & & 143,02 & \\
Meslekte Çalışma Süresi & 91 & 129,59 & \\
$1-5$ yıl & 49 & 120,68 & \\
$6-10$ yıl & 56 & 90,29 & \\
$11-15$ yıl & 23 & 116,02 & \\
$16-20$ yıl & 17 & 149,12 & \\
20 yıldan fazla & & & \\
Eğitim Düzeyi & 43 & 149,85 & \\
Lise & 55 & 121,40 & \\
Önlisans & 132 & 106,86 & \\
Lisans & 6 & 123,25 & \\
Lisans üstü & & & \\
\hline
\end{tabular}

* Kuruskal-Wallis test

Mann-Whitney $U$ testi ve Kuruskal-Wallis testinden elde edilen sonuçlara göre de, \%5 anlamlılık seviyesinde internet kullanım saati ve internet kullanım amacı ile aleksitimi arasında anlamlı bir farklılık bulunmaktadır. İnternet kullanım saati arttıkça aleksitimi düzeyi de artış göstermektedir. Bunun yanında interneti sosyal medyaya girmek için kullanan katılımcılar, araştırma yapmak, bilgi edinmek ya da internette gezinmek için 
kullanan katılımcılardan daha fazla aleksitimik olmaktadır. Araştırma verilerine göre, \%5 anlamlılık seviyesinde sosyal medya kullanma ve sosyal medya kullanma süresi ile aleksitimi arasında anlamlı bir farklılık bulunmamaktadır. Ancak veriler incelendiğinde sosyal medya kullanımı arttıkça aleksitimi düzeyinin de artış gösterdiği görülmektedir (Tablo 6).

Tablo 6. İnternet ve Sosyal Medya Kullanma Pratiklerine Göre Aleksitimi Düzeyi

\begin{tabular}{|c|c|c|c|}
\hline \multirow[b]{2}{*}{ Variables } & \multicolumn{3}{|c|}{ Aleksitimi Düzeyi } \\
\hline & $\mathrm{N}$ & $\mathrm{M}$ & $\mathrm{p}$ \\
\hline \multicolumn{4}{|l|}{ İnternet Kullanım Saati* } \\
\hline 1 saatten az & 37 & 117,03 & \\
\hline $1-3$ saat & 128 & 106,39 & \\
\hline 4-6 saat & 55 & 134,29 & 0,02 \\
\hline $7-9$ saat & 10 & 135,65 & \\
\hline 9 saatten fazla & 3 & 190,65 & \\
\hline \multicolumn{4}{|l|}{ İnternet Kullanım Amaci* } \\
\hline Sosyal paylaşım ağlarına girmek & 76 & 128,93 & \\
\hline Araştırma yapmak ve bilgi edinmek & 24 & 122,35 & 0,00 \\
\hline İnternette gezinmek & 107 & 97,29 & \\
\hline Oyun oynamak & 17 & 148,79 & \\
\hline Diğer & 8 & 169,25 & \\
\hline \multicolumn{4}{|l|}{ Sosyal Medya Kullanma** } \\
\hline Evet & 206 & 118,39 & 0,95 \\
\hline Hayır & 30 & 119,27 & \\
\hline \multicolumn{4}{|l|}{ Sosyal Medya Kullanma Süresi* } \\
\hline 1 saatten az & 56 & 102,38 & \\
\hline $1-3$ saat & 116 & 102,73 & 0,11 \\
\hline 4-6 saat & 30 & 114,40 & \\
\hline $7-9$ saat & 10 & 149,60 & \\
\hline
\end{tabular}

${ }^{*}$ Kuruskal-Wallis test

** Mann-Whitney U test

\section{Tartışma ve Sonuç}

Acil serviste çalışan hemşirelerin internet ve sosyal medya kullanım alışkanlıklarını ve aleksitimi düzeylerini tespit etmek için saha araştırması yapılmıştır. Araştırma verilerinin analizinden elde edilen sonuçlara göre, yapılan mesleğe göre kadın erkek oranının dengeli olduğu, katılımcıların yaşlarının orantılı dağıldığı ancak genel çerçevede genç katılımcıların daha fazla olduğu görülmektedir. Çünkü acil servis hemşireliği mesleğini kadınlar erkeklere göre daha fazla tercih etmektedir. Bu yüzden bu meslek dalında kadın sayısı erkek sayısından daha fazladır. Ayrıca yorucu ve güç isteyen bu mesleği icra etmek için fizik kuvvetine ihtiyaç olmakta ve genç yaşta olma avantaj sağlayan bir unsur olmaktadır. Bu sebeple katılımcıların önemli bir kısmı genç yaştaki bireylerdir. Dahası, bu mesleğe kabul edilmek için belli bir düzeyde eğitim seviyesine de sahip olmak gerekmektedir. Bu sebeple katılımcıların çok büyük bir kısmı en az önlisans düzeyinde bir eğitime sahiptir. Bunun yanında katılımcıların yarısı evli, diğer yarısı da bekar olmakta ve yaşları doğrultusunda bu 
mesleği farklı sürelerde icra etmektedirler. Ayrıca nüfus sayısı arttıkça şehirlerdeki hastane sayısı da artış göstermekte, dolayısıyla büyük şehirlerde çalışan hemşire sayısı da küçük illere göre daha fazla olmaktadır. Bu yüzden Ankara'daki katılımcıların fazla olması anlaşılır olmaktadır.

Çalışmaya dahil olan katılımcıların internet ve sosyal medya kullanım alışkanlıkları incelendiğinde, hem interneti hem de sosyal medyayı süre noktasında az kullandıkları anlaşılmaktadır. Katılımcıların büyük çoğunluğu bu sanal ortama günde en fazla 3 saat zaman ayırmaktadır. Bunun haricinde katılımcılar internetti en fazla bu ağda gezinmek için kullanmakta, çok büyük çoğunluğu sosyal medyaya girmekte, az sayıda sosyal paylaşım ağına sahip olmakta ve sosyal medyayı en çok gündemi takip etmek için kullanmaktadır. Acil serviste çalışan hemşireler, işlerinin yoğunluğu, işlerinin ciddiyeti ve eğitimli olmaları hasebiyle bu sanal ağda çok uzun süre vakit harcamamaktadır.

Katılımcıların aleksitimi düzeylerine bakıldığında ise, "duyguları tanımada zorluk" ve "duyguları ifade etmede zorluk" alt boyutlarında aleksitimik olmadıkları ancak "dışa dönük düşünce" alt boyutunda orta derecede aleksitimik oldukları tespit edilmiştir. Genel çerçeveden bakıldığında ise katılımcıların aleksitimik olmadıkları ancak orta derecede aleksitimik olmaya çok yakın oldukları görülmektedir. Katılımcıların aleksitimi düzeylerine demografik özellikler noktasında bakıldığında ise cinsiyet faktörü hariç bütün faktörlerde anlamlı farklılıkların olduğu ortaya çıkarılmıştır.

Verilere göre cinsiyet ile aleksitimi arasında anlamlı bir farklılık yoktur. Yapılan diğer çalışmalarda da aleksitimi ile cinsiyet değişkeni arasında anlamlı farklılığın bulunmadığı görülmüştür (Mattila et. al., 2006; Çaka vd., 2018: 1001; Aksoy ve Çoban, 2017: 49; Batıgün ve Büyükşahin, 2008: 110). Ancak bazı araştırmalarda ise aleksitiminin görülme oranının erkeklerde daha fazla olduğu sonucuna varılmıştır (Honkalampi et. al., 2000). Bunun yanında, bekar bireylerin aleksitimi düzeylerinin evli bireylere göre daha fazla olduğu, Yozgat'ta yaşayan katılımcıların aleksitimi düzeylerini de Ankara'da yaşayan katılımcılara göre daha fazla olduğu tespit edilmiştir.

Ayrıca, yaş, meslekte çalışma süresi ve eğitim düzeyi ile aleksitimi arasında da anlamlı farklılıklar mevcuttur. 45 veya üzeri yaşta bulunan katılımcılar daha küçük yaştaki katılımcılara göre daha fazla aleksitimik olmaktadırlar. Aynı şekilde 20 yıldan fazladır bu mesleği icra eden katılımcıların aleksitimi düzeyleri, bu mesleği daha az zamandır yapan katılımcılara göre daha fazladır. Yani yaş ve meslekte kalma süresi arttıkça aleksitimi düzeyi de artış göstermektedir. Ayrıca lise düzeyinde eğitim seviyesine sahip olan katılımcılar, daha fazla eğitim düzeyine sahip olan katılımcılara göre daha fazla aleksitimik olmaktadırlar Batıgün ve Büyükşahin'in (2008: 110) yaptıkları araştırmada da, aleksitimi ile eğitim arasında anlamlı bir ilişki gözlenmiştir. Araştırmaya göre eğitim düzeyi düşük olan bireyler daha aleksitimik görünmektedirler. Aynı şekilde Kirmayer ve Robbins'in (1993) araştırmasına göre de, aleksitiminin düşük eğitim düzeyi ile ilişkili olduğu, eğitim düzeyi arttıkça aleksitimi düzeyinin azaldığı ileri sürülmüştür.

İnternet ve sosyal medya kullanımı ile aleksitimi arasındaki ilişki analiz edildiğinde ise, internet kullanım saati ve internet kullanım amacı ile aleksitimi arasında anlamlı bir farklılık bulunduğu tespit edilmiştir. İnternet kullanım saati arttıkça aleksitimi düzeyi de artış göstermektedir. Bunun yanında interneti sosyal paylaşım ağına girmek için kullanan 
katılımcılar, araştırma yapmak, bilgi edinmek ya da internette gezinmek için kullanan katılımcılardan daha fazla aleksitimik olmaktadır. Araştırma verilerine göre, $\% 5$ anlamlılık seviyesinde sosyal paylaşım ağı kullanma ve sosyal paylaşım ağı kullanma süresi ile aleksitimi arasında anlamlı bir farklılık bulunmasa da veriler incelendiğinde sosyal paylaşım ağı kullanımı arttıkça aleksitimi düzeyinin de artış gösterdiği ortaya çıkarılmıştır.

\section{Kaynakça}

Aksoy, M., Çoban, G. İ. (2017). Hemşirelik Öğrencilerinin Aleksitimi Düzeylerinin Bazı Değişkenler Açısından İncelenmesi. Hemşirelikte Eğitim ve Araştırma Dergisi, 14 (1), 45-51.

Batıgün, A. D., Büyükşahin, A. (2008). Aleksitimi: Psikolojik Belirtiler ve Bağlanma Stilleri. Klinik Psikiyatri, 11, 105-114.

Bolat, N., Yavuz, M., Eliaçık, K., Zorlu, A., Evren, C., Köse, S. (2017). Psychometric Properties of the 20-Item Toronto Alexithymia Scale in a Turkish Adolescent Sample. Anatolian Journal of Psychiatry, 18 (4), 362-368.

Çaka, S. Y., Topal, S., Nemut, T., Çınar, N. (2018). Hemşirelik ve Ebelik Öğrencilerinde Aleksitimi ile Empati Arasındaki İlişki. Journal of Human Sciences, 15 (2), 996-1005.

Epözdemir, H. (2012). Aleksitimi: Psikolojik Bir Semptom mu, Yoksa Bir Kişilik Özelliği mi? Türk Psikoloji Yazıları, 15 (30), 25-33.

Ersoy, E. (2013). Değişen Dünyada, Değerlere Değmek. Düşünce Dünyasında Türkiz Siyaset ve Kültür Dergisi, 23, 7-28.

Fuchs, C. (2011). An Alternative View of Privacy on Facebook. Information, 2, 140-165.

Hendryx, M. S., Haviland, M. G., Shaw, D. G. (1991). Dimensions of Alexithymia and Their Relationship to Anxiety and Depression. J Pers Assess, 56, 227-237.

Honkalampi, K., Hintikka, J., Saarinen, P., Lehtonen, J., Viinamäki, H. (2000). Is Alexithymia a Permanent Feature in Depressed Patients? Results from a 6-Month Follow-up Study. Psychother Psychosom, 69 (6), 303-308.

Kamel N. M. F. (2013). The Relationship Between Emotional Awareness and Empathetic Response Among Psychiatric Hospital Staff. Life Science Journal, 10 (3), 1272-1284.

Karagülle, A. E., Çaycı, B. (2014). A ̆̆ Toplumunda Sosyalleşme ve Yabancılaşma. The Turkish Online Journal of Design, Art and Communication, 4 (1), 1-9.

Kauhanen, J., Kaplan, G. A:, Julkunen, J., Wilson. T. W., Salonen, J. T. (1993). Social Factors In Alexithymia. Comprehensive Psychiatry, 34 (5), 330-335.

Kirmayer, L. J., Robbins, J. M. (1993). Cognitive and Social Correlates of the Toronto Alexithymia Scale. Psychosomatics, 34 (1), 41-52.

Koçak, R. (2002). Aleksitimi: Kuramsal Çerçeve Tedavi Yaklaşımları ve İlgili Araştırmalar. Ankara Üniversitesi Eğitim Bilimleri Fakültesi Dergisi, 35 (1), 183-212.

Mattila, A. K., Salminen, J. K., Nummi, T., Joukamaa M. (2006). Age is Strongly Associated with Alexithymia in the General Population. Journal of Psychosomatic Research, 61 (5), 629-635.

Mayfield, (2019). What is Social Media? https://www.icrossing.com/uk/sites/default/files_uk/insight_pdf_files/What $\% 20$ is\%20Social\%2 0Media_iCrossing_ebook.pdf, Access Date: 07.04.2019. 
Oktay, B., Batıgün, A. D. (2014). Aleksitimi: Bağlanma, Benlik Algısı, Kişilerarası İlişki Tarzları ve Öfke. Türk Psikoloji Yazıları, 17 (33), 31-40.

Parlayan, M. A., Dökme, S. (). Özel Hastanelerdeki Hemşire ve Hastaların İletişim Seviyelerinin Değerlendirilmesi: Bir Hastane Örneği. KSÜ Sosyal Bilimler Dergisi, 13 (2), 265-284.

Sifneos, P. E. (1972). Short-term Psychotherapy and Emotional Crisis. Cambridge: Harvard University Press.

Stokowski, L. A. (2011). Social Media and Nurses: Promising or Perilous? https://www.medscape.com/viewarticle/753317, Access Date: 05.04.2019.

Şaşıŏ̆lu, M., Gülol, Ç., Tosun, A. (2013). Aleksitimi Kavramı. Psikiyatride Güncel Yaklaşımlar, 5 (4), 507-527.

Şentürk, Ü. (2013). Milenyum Gençliğinin Dijital Yaşamı: Küresel Gençlik Kültürünü Sosyal Medyada Okumak. Düşünce Dünyasında Türkiz Siyaset ve Kültür Dergisi, 23, 29-46.

Taylor, G. J., Ryan, D., Bagby, R. M. (1985). Toward the Development of a New Self-report Alexithymia Scale. Psychotherapy and Psychosomatics, 44 (4), 191-199.

Uygun, E., Akbulut, D. (2018). Karnavalesk Kuramı ve Instagram Ortamına Yansımaları. Yeni Medya Elektronik Dergi, 2 (2), 73-89. 